\title{
Jean Haritschelhar (1-IX-2013)
}

2010. urtean Madrileko UNEDeko egoitza nagusian Jean Haritschelhar irakaslearekin Doctor Honoris Causa izendapena zela eta, egun pare bat elkarrekin pasatzeko aukera izan genuen berton lanean aritzen garen irakasleok. Aipatu ekitaldian Xesús Alonso Montero, Antoni Maria i Margarit, Humberto López Morales eta Haritschelhar doktoreak, galego, katalana, gaztelania eta euskaren ordezakariak, hurrenez hurren, UNEDeko ohorezko errekonozimendua jaso zuten. Oholtzan zeudenenen ibilbide profesionala luze bezain sakona zela jakin bagenekien filologook baina, Haritschelharrek giza harremanetan maiusuki eta gozoki jokatzeko trebetasunaren lekukoak izateko aukera izan genuen euskal irakaslea momentu hori arte gertutik ezagutzen ez genuenok. Madrilera, P. Urkizu irakaslearen proposamen akademikoak ekarri zuen baina Madriletik joan zenean filologoa baino, adiskidea joan zitzaigula antzeman genuen UNEDen.

Gazte garaiko oroitzapenak aletu zizkigun gurean egon zenean: frankismo aroko Sorbonako ikasle baten bizipenak, harridunak eta gaztelaniazko literaturarako miresmena; Madril grixaska alde batetik, eta bestetik, gaztaroko gogoberotasunaren dizdiraren arteko kontrastea espainola ikasten ari zela: literaturaren urre kolorea eta diktaduraren uhertasuna. Sevillako egonaldiko xehetasunak biziki gogoratzen zituen: kaleak, parkeak, museoak... Eta berriro ere, hiri horietan irakurri zuena.

Bordeleko Unibertsitateko katedraduna, Euskaltzaindiko burua 1989-2004 aldian, Baigorriko alkatea, Baionako museoko zuzendaria, Lapurdum aldizkariaren sortzaile eta Eusko Ikaskuntzaren Manuel Lekuona saridunak (2004) bizitzan hiru lema zituela adierazi zion Sustrai Colinak Argian (1227 alean) eginiko elkarrizketan: euskalduna naiz sortzez, frantsesa legez, eta europearra ametsez, Gauden gu eta jo aitzina eta Jasan baina iraun, hau da, amets egiteko gaitasuna, erresistentzia eta iraunkortasunaren aldeko nortasunaren jabe genuen, kultura eta engaiamendu uztartzen zituen irakaslea.

Etxauni buruzko tesi ondoren laurehun artikulutik gora idatzi zituen. Villasanteren ondorengo aldian Euskaltzaindiaren aro berritzaile eta oparoan gidatu zuen. Hortxe ditugu Orotariko Hiztegia, Hizkuntz Atlasa, batzordeen berrantolamendua abiatu izana, besteak beste. Patxi Zabaletak (Diario de Navarra, 201309-13), Haritschelhar zendu berria zenean, euskararen plaza gizon gisa deskribatu zigun irakasle baigorritarra. Haren erudizioaz gain, euskal gizartearen konfiantza lortu izana, hots, euskara eta euskal kulturaren aldeko giza mugimenduak Euskaltzaindiarako lotura eta sostengua eskuratu izana zor diogu. Akademizismo hutsal batetik urrun, «eman ta zabal zazu» aldeko doktore eta maisu ahaztuezina. Zilegi esan bekigu, omenaldi moduan, haren lemetako bat gurea izan dadila: Gauden gu eta jo aitzina. 